ROCZNIK POLSKO-NIEMIECKI 2018, nr 26

ISSN $1230-4360$

DOI: $10.35757 /$ RPN.2018.26.10

\author{
Michat Matheja \\ Dom Współpracy Polsko-Niemieckiej \\ Gliwice-Opole
}

\title{
Centrum Badań Mniejszości Niemieckiej
}

\section{Geneza}

W 2010 roku przy nie pierwszym we współczesnej historii Okragłym Stole zasiedli przedstawiciele rządów Republiki Federalnej Niemiec, Rzeczypospolitej Polskiej, przedstawiciele mniejszości niemieckiej w Polsce i Polaków w Niemczech oraz specjaliści z zakresu działalności tych grup. Celem podjętych rozmów było „dokonanie przeglądu obecnego stanu realizacji postanowień Traktatu (chodzi o Traktat między Rzeczapospolita Polska a Republika Federalna Niemiec o dobrym sqsiedztwie i przyjaznej wspótpracy z 1991 roku) oraz wypracowanie działań dotyczacych realizacji ustalonych w Traktacie praw dla obywateli niemieckich polskiego pochodzenia i Polaków w Republice Federalnej Niemiec oraz mniejszości niemieckiej w Polsce"'.

12 czerwca 2011 roku podpisane zostało Wspólne Oświadczenie Okragłego Stołu, sygnowane przez Sekretarza Stanu w Ministerstwie Spraw Wewnętrznych i Administracji Tomasza Siemoniaka, parlamentarnego Sekretarza Stanu w Federalnym Ministerstwie Spraw Wewnętrznych Christopha Bergnera, przewodniczącego Związku Niemieckich Stowarzyszeń Społeczno-Kulturalnych w Polsce Bernarda Gaidę, przewodniczącego Konwentu Organizacji Polskich w Niemczech Wiesława Lewickiego oraz przewodniczącego Związku Polaków w Niemczech „Rodło” Marka Wójcickiego².

Polsko-Niemiecki ,,Okragly Stót i jego ustalenia”,http://skgd.pl/dzialalnosc-polityczno-spoleczna/aktywnosc-polityczna/polsko-niemiecki-okragly-stol-i-jego-ustalenia/ (dostęp: 13 marca 2018).

2 Wspólne Oświadczenie Okragłego Stołu w sprawie wspierania obywateli niemieckich polskiego pochodzenia i Polaków w Niemczech oraz niemieckiej mniejszości w Polsce, zgodnie z polsko-niemieckim Traktatem o dobrym sasiedztwie i przyjaznej wspótpracy, http://www.msz.gov. pl/resource/9a4e3414-2904-4dec-bd93-56dc761c8f13:JCR (dostęp: 13 marca 2018). 
W celu wspierania mniejszości niemieckiej w Polsce strona polska zobowiązała się m.in. do „utworzenia, w ramach organizacji mniejszości niemieckiej komórki, która działając na bazie naukowej podejmie i będzie koordynowała badania dotyczące mniejszości niemieckiej, jej historii i dziedzictwa kulturowego"3. Z kolei strona niemiecka zadeklarowała powołanie Centrum Dokumentacji Kultury i Historii Polaków w Niemczech. Symboliczna inauguracja pracy tej placówki nastapiła 28 czerwca 2013 roku w Bochum. Przyjęła ona nazwę „Porta Polonica”. W wywiadzie udzielonym redakcji Deutsche Welle zastępca pełnomocnika rządu federalnego ds. kultury i mediów Günter Winands nazwał wówczas Centrum Dokumentacji „,ważnym komponentem badań w zakresie historii i kultury Polaków w Niemczech i Niemców o polskich korzeniach" i podkreślił, że rząd RFN zobowiązał się do finansowania przedsięwzięcia sumą 300 tys. euro rocznie - na czas nieokreślony ${ }^{4}$.

Tymczasem w Polsce instytucją, która jako pierwsza podjęła działania na rzecz realizacji utworzenia przewidzianej w umowie „komórki”, był Dom Współpracy Polsko-Niemieckiej (DWPN). We wrześniu 2014 roku DWPN złożył w ramach corocznej procedury wniosek o środki na podjęcie projektu zatytułowanego „Instytut Niemiecki”. Decyzją ministra administracji i cyfryzacji z 16 grudnia 2014 roku w sprawie podziału dotacji na realizację w roku 2015 zadań mających na celu ochronę, zachowanie i rozwój tożsamości kulturowej mniejszości narodowych i etnicznych oraz zachowanie i rozwój języka regionalnego na działania zaplanowane w ramach „Instytutu” przyznano $73880 \mathrm{zt}^{5}$.

Oficjalna inauguracja prac związanych z nową inicjatywą nastapiła 1 marca 2015 roku. Koordynatorka projektu została Julianna Klick. Na wniosek Rady Programowej DWPN już 1 kwietnia dyrektor tej instytucji, Rafał Bartek, zwrócił się do dotacjodawcy z prośbą o korektę tytułu zadania. „Instytut Niemiecki” zastapiony został stosowanym do dzisiaj określeniem „Centrum Badań Mniejszości Niemieckiej”. Decyzja ta podyktowana była stanowiskiem Rady, że sformułowanie „instytut” byłoby utożsamiane z pracownią badawczą, działającą w ramach jednostki naukowej, tymczasem nowa „komórka" funkcjonować będzie przy organizacji pozarządowej.

Ważniejszym od przyjętego tytułu projektu był i pozostaje jednak jego cel. Jest nim podtrzymanie i rozwój tożsamości mniejszości niemieckiej, możliwe jedynie w oparciu o solidną wiedzę, popartą badaniami naukowymi. Specyfika prac badawczych podejmowanych w nawiązaniu do społeczności niemieckiej w Polsce związana jest $\mathrm{z}$ faktem, że do roku 1989 tematyka ta obciążona była obowiązująca wówczas ideologia, a zwłaszcza teza, że niemal wszyscy Niemcy opuścili Polskę po II wojnie światowej. Dopiero po przełomie ustrojowym możliwe stało się zainicjowanie badań naukowych niezależnych od wpływów politycznych.

\section{Ibidem.}

4 „Porta Polonica”. Jest centrum dokumentacji historii niemieckiej Polonii,http://www.dw. com/pl/porta-polonica-jest-centrum-dokumentacji-historii-niemieckiej-polonii/a-16916066 (dostęp: 13 marca 2018).

5 Decyzja Ministra Administracji i Cyfryzacji z dnia 16 grudnia 2014 r., http://mniejszosci.narodowe.mswia.gov.pl/mne/dotacje/2015/dotacje/8548,Decyzja-Ministra-Administracji-i-Cyfryzacji-z-dnia-16-grudnia-2014-r.html (dostęp: 13 marca 2018). 


\section{Rada Naukowa}

Jednym z pierwszych działań podjętych w ramach realizacji zadania było powołanie Rady Naukowej. W jej składzie znaleźli się naukowcy reprezentujący różne dyscypliny naukowe i ośrodki akademickie, zajmujący się problematyką wchodzącą w zakres zainteresowań Centrum, jak również przedstawiciele środowiska mniejszościowego. W początkowym okresie Rada liczyła 16 członków, aktualnie w jej pracach bierze udział 21 osób $^{6}$. W pierwszym roku działania spotkania tego gremium odbywały się ze znacznie większą częstotliwością - sześciokrotnie w 2015 roku, obecnie posiedzenia zwoływane są 2-3 razy w roku. Część członków Rady uczestniczy w podejmowanych zadaniach i pozostaje w stałym, bezpośrednim kontakcie z Domem Współpracy Polsko-Niemieckiej i aktualnym koordynatorem projektu - autorem tego tekstu.

Podstawowym celem powołania tego gremium jest określenie obszarów prowadzonych badań, wskazanie ich metod - dostosowanych do możliwości Centrum - i tworzenie koncepcji dalszego rozwoju projektu. Co roku jeden z członków Rady opracowuje raport $\mathrm{z}$ jej spotkań udostępniany na stronie internetowej projektu? ${ }^{7}$.

\section{Wywiady pogłębione}

Kwestią podnoszona, poczynając od pierwszego spotkania Rady, była konieczność pilnego podjęcia działań na rzecz zachowania wspomnień i świadectw najstarszego pokolenia Niemców w Polsce. Od roku 2016 naukowcy współpracujący z Centrum przeprowadzają wywiady z osobami pochodzenia niemieckiego w pięciu województwach, w których liczebność członków mniejszości jest największa - śląskim, opolskim, dolnośląskim, pomorskim i warmińsko-mazurskim. Rozmowy te poddawane są transkrypcji i udostępniane do celów naukowych. Wywiady przeprowadzane są w formie wywiadów swobodnych na podstawie dyspozycji stanowiących jedynie zarysowane ramy rozmowy. Autorką kwestionariusza jest uczestnicząca również osobiście w badaniach dr Irena $\mathrm{Ku}-$ rasz (Uniwersytet Wrocławski). Listę otwierają pytania dotyczące wydarzeń roku 1945 i pierwszych lat powojennych, sytuacji ludności niemieckiej w tym okresie, wysiedleń, kwestii zmiany imion i nazwisk. Kolejne poruszane w rozmowach zagadnienia związane są z odwilżą polityczną zapoczątkowaną w 1956 roku, życiem codziennym w PRL, zwłaszcza w kontekście możliwości używania i nauczania języka niemieckiego, kontaktów z kulturą niemiecką oraz kontaktów z rodzinami mieszkającymi w RFN i NRD. Wreszcie w ostatniej części wywiadów badacze koncentrują się na kwestiach legalizacji (bądź odrodzenia) organizacji mniejszościowych na przełomie lat osiemdziesiątych i dziewięćdziesiątych XX wieku, a także obecnym położeniu i perspektywach społeczności mniejszościowej. Zgromadzone wypowiedzi wyraźnie pokazuja, że choć wiele doświadczeń jest wspólnych dla mieszkańców poszczególnych województw, to jednak łatwo dostrzec specyfikę regionalną, zwłaszcza ze względu na różny status Niemców

6 Centrum Badań Mniejszości Niemieckiej, Rada Naukowa, http://www.haus.pl/cbmn-rada.html (dostęp: 13 marca 2018).

7 Centrum Badań Mniejszości Niemieckiej, http://www.haus.pl/cbmn-projekt.html (dostęp: 13 marca 2018). 
w Polsce w czasach PRL. W zasobach Centrum zgromadzonych zostało już 50 takich wywiadów, dalszych 20 zaplanowano na rok 2018.

\section{Wywiady z zalożycielami organizacji mniejszościowych}

Kolejną inicjatywą podjętą w ramach projektu od pierwszego roku jego funkcjonowania było zapisywanie wspomnień osób zaangażowanych w tworzenie struktur organizacji mniejszościowych w okresie przełomu ustrojowego. Przeprowadzenie tej grupy wywiadów jest jednym z zadań koordynatora projektu. W roku 2015 pierwszych 15 nagrań zostało zrealizowanych w województwie opolskim, rok później działanie to rozszerzono na województwa: śląskie i dolnośląskie, zaś w kolejnym roku - także na województwa: lubuskie i wielkopolskie. Kwestionariusze - dostosowane do specyfiki regionów - opracowali dr Magdalena Lemańczyk (Instytut Kaszubski) i dr Paweł Popieliński (Instytut Studiów Politycznych Polskiej Akademii Nauk). Chociaż głównym wątkiem rozmów są wydarzenia prowadzące do rejestracji stowarzyszeń mniejszości niemieckiej w 1990 roku (w niektórych przypadkach także w latach późniejszych), proces budowania zrębów organizacji oraz działania podejmowane w latach kolejnych, to również podczas tych wywiadów pojawiają się odwołania do okresu wcześniejszego. Prowokują do tego pytania o doświadczenia - pozytywne i negatywne - związane z pochodzeniem respondentów czy ich motywacjami. Rozmowy przeprowadzane są zarówno z działaczami najwyższego szczebla organizacji mniejszościowych, wśród nich z byłymi parlamentarzystami, jak i z aktywistami lokalnych kół stowarzyszeń. Pozwala to na uzyskanie szerokiego spektrum wypowiedzi. Szczególną i bardzo cenną grupę wspomnień stanowią relacje osób zaangażowanych w wysiłki na rzecz legalizacji stowarzyszeń Niemców na Górnym Śląsku już na kilka lat przed rokiem 1989. Ze względu na prowadzoną w schyłkowym okresie PRL politykę skłaniania ówczesnych aktywistów do emigracji, zdecydowana większość z nich żyje obecnie za granica. Z kolei nagrania z terenu Dolnego Śląska ukazują proces odradzania się życia społeczności mniejszościowej w tym okresie. Wprawdzie obejmujące cały region Niemieckie Towarzystwo Społeczno-Kulturalne z siedzibą w Wałbrzychu powstało już w maju 1957 roku, a władze PRL nigdy nie zaprzeczały istnieniu stosunkowo nielicznej grupy Niemców na tym terenie, to jednak po wprowadzeniu stanu wojennego działalność tej organizacji niemal zamarła.

Spośród 55 przeprowadzonych dotąd wywiadów 30 zrealizowanych zostało na terenie działania TSKN na Śląsku Opolskim, 18 - TSKN Województwa Śląskiego, 5 na Dolnym Śląsku i po jednym w Zielonej Górze i Pile. Rozmówcy z terenu Górnego Śląska reprezentowali różne środowiska, także takie, w których obecnie liczba Niemców jest już niewielka - jak np. na Śląsku Cieszyńskim. W wielu miejscach działacze organizacji lokalnych udostępnili koordynatorowi projektu cenne materiały archiwalne, które zostały zdigitalizowane i wraz z transkrypcjami wywiadów udostępniane są naukowcom.

\section{Konferencje i debaty}

Zadaniem Centrum jest nie tylko gromadzenie wiedzy, ale także jej rozpowszechnianie. Dlatego jedną z form realizacji projektu jest organizacja debat i konferencji poświęconych wybranym tematom. 
Pierwsza debata zatytułowana „Niemcy w Polsce w powojennym czterdziestoleciu - od wysiedleń i odniemczania do legalizacji mniejszości” została przeprowadzona 26 września 2015 roku we wrocławskiej Hali Stulecia i towarzyszyła V Festiwalowi Kultury Mniejszości Niemieckiej. W debacie moderowanej przez dr Irenę Kurasz udział wzięli: dr Danuta Berlińska (Uniwersytet Opolski), prof. Piotr Madajczyk (Instytut Studiów Politycznych Polskiej Akademii Nauk), dr Bernard Linek (Instytut Śląski w Opolu) oraz Renate Zajączkowska (wiceprzewodnicząca Zarządu Związku Niemieckich Stowarzyszeń Społeczno-Kulturalnych w Polsce).

Druga debata, nawiązująca do przypadającej 35. rocznicy powstania NSZZ „Solidarność" oraz 25. rocznicy rejestracji organizacji mniejszościowych w większości regionów została przeprowadzona 17 listopada 2015 roku na Wydziale Filologicznym Uniwersytetu Gdańskiego pod tytułem „Solidarność wobec Niemców w Polsce - Niemcy w Polsce wobec Solidarności”. Współorganizatorem debaty była Pracownia Badań nad Narracjami Pamięci Pogranicza Uniwersytetu Gdańskiego. Spotkanie moderowała dr Magdalena Lemańczyk, zaś w panelu dyskusyjnym udział wzięli eksperci: prof. Piotr Madajczyk, prof. Andrzej Friszke (Instytut Studiów Politycznych PAN), dr Zbigniew Bereszyński (badacz niezależny z Opola), prof. Józef Borzyszkowski (Uniwersytet Gdański) oraz Roland Hau (przewodniczący Związu Mniejszości Niemieckiej w Gdańsku). Zapis dyskusji poprzedzony wstępem prof. Piotra Madajczyka opublikowany został w numerze 24. „Rocznika Polsko-Niemieckiego” z 2016 roku$^{8}$.

W kolejnym roku w ramach projektu Centrum zorganizowane zostały dwie jednodniowe konferencje naukowe. Pierwsza z nich odbyła się 25 października 2016 roku w Zabrzu. Tematem była niezwykle istotna, ale i ciekawa z punktu zachowania tożsamości mniejszości kwestia „Wpływu granic administracyjnych i ich zmian na tożsamość mieszkańców”. Moderacji podjął się Sebastian Rosenbaum (Instytut Pamięci Narodowej).

Mniejszość niemiecka w Polsce w swoim współczesnym kształcie powstała w wyniku zmiany przebiegu granicy polsko-niemieckiej po II wojnie światowej. Prof. Krzysztof Gładkowski (Uniwersytet Warmińsko-Mazurski w Olsztynie) poświęcił swój referat pt. „Kim jestem w zmieniającym się świecie?” dwóm pojęciom zawartym w tytule konferencji - zmianie i tożsamości.

Nie było dziełem przypadku, że na miejsce konferencji wybrane zostało Zabrze. Jak wykazał drugi referent ks. prof. Kazimierz Dola (Uniwersytet Opolski), sam urodzony w stanowiącym dziś dzielnicę miasta Pawłowie, okolice Zabrza już od średniowiecza stanowiły teren pogranicza. Jednak kluczowym wydarzeniem z punktu widzenia kształtowania się tożsamości mieszkańców był podział Górnego Śląska w 1922 roku. Część miejscowości należących obecnie do Zabrza znalazła się po polskiej stronie granicy, inne - w tym współczesne centrum - po niemieckiej. Decyzja o pozostaniu w miejscu dotychczasowego zamieszkania bądź o „wewnątrzśląskiej” emigracji wpływała na dalsze losy, ale także na poczucie narodowej przynależności. Przedwojenna granica państwowa dzieli zresztą zabrzan do dzisiaj, jako granica między katolickimi diecezjami: gliwicką i katowicką.

8 Dyskusja panelowa , Solidarność wobec Niemców w Polsce - Niemcy w Polsce wobec Solidarności”, „Rocznik Polsko-Niemiecki” 2016, nr 24, z. 1, s. 251-306. 
Dr Irena Kurasz przedstawiła zupełnie odmienną (w porównaniu z Górnym Śląskiem) sytuację Niemców z Dolnego Śląska, którzy po II wojnie światowej znaleźli się na swego rodzaju kulturowym pograniczu. $Z$ jednej strony funkcjonują oni od dziesięcioleci w znacznym rozproszeniu, z drugiej - znacznie wcześniej zostali uznani jako mniejszość narodowa. Jednak ze względu na fakt, że żyją z reguły w rodzinach mieszanych, dolnośląscy Niemcy przejęli wiele elementów polskiej tradycji, jednocześnie nie rezygnując z kultywowania własnych obyczajów.

W ostatnim referacie dr Marcin Jarząbek (Uniwersytet Jagielloński) zaprezentował własne doświadczenia i rezultaty badań przeprowadzonych na dawnym pograniczu polsko-niemieckim przy użyciu metody historii mówionej. Pokusił się także o sformułowanie potencjalnych odpowiedzi na pytanie o wpływ „starej granicy” na tożsamość młodych mieszkańców tych ziem.

Druga zaplanowana na rok 2016 konferencja odbyła się 17 listopada w Opolu. Już sam tytuł „Czego jeszcze nie wiemy o losach Niemców w Polsce po 1945 roku?“ zdefiniował jej program. Odpowiedź, czy też raczej odpowiedzi stanowić winny drogowskazy do dalszych działań Centrum Badań Mniejszości Niemieckiej. Moderatorem konferencji był Krzysztof Wysdak (Towarzystwo Społeczno-Kulturalne Niemców na Śląsku Opolskim).

W pierwszym wystapieniu prof. Piotr Madajczyk skoncentrował się na wskazaniu najważniejszych obszarów badawczych, które do tej pory nie zostały jeszcze poddane głębszej analizie. W przekonaniu autora warto byłoby przeanalizować wpływ czterech czynników działających na pozostałych w Polsce Niemców: oficjalnej propagandy, Niemiec (przede wszystkim za pośrednictwem prywatnych kontaktów), Kościoła oraz Polskiej Zjednoczonej Partii Robotniczej. Referent wskazał też brak źródeł (poza oficjalnymi) jako przeszkodę w podejmowaniu tej tematyki. Za tym istotniejsze uznał - podejmowane także w ramach Centrum Badań Mniejszości Niemieckiej - wysiłki na rzecz zachowania dokumentów, listów, fotografii, do dzisiaj znajdujących się w rękach prywatnych.

Trzy kolejne wystapienia poświęcone zostały zaprezentowaniu sytuacji mniejszości w regionach, które - w porównaniu z Górnym Śląskiem - traktowane są niekiedy marginalnie. Dr Magdalena Lemańczyk przedstawiła położenie Niemców na Pomorzu. Wskazała przy tym na wewnętrzne zróżnicowanie tej grupy. Zarówno historycznie, jak i współcześnie miejsce zamieszkania wpływało na używany język czy kultywowaną tradycję. Szczególną grupę stanowią w tym kontekście ,starzy” gdańszczanie. Poza dużymi miastami wielu członków mniejszości to osoby o tożsamości mieszanej z elementami niemieckimi, polskimi i kaszubskimi.

Prof. Krzysztof Gładkowski nawiązał do prowadzonych wywiadów z najstarszymi Mazurami i Warmiakami. Przedstawił dramatyczne doświadczenia ostatnich miesięcy II wojny światowej, które odcisnęły piętno na dalszych losach mieszkańców dawnych Prus Wschodnich. Wprawdzie - w porównaniu z Pomorzem czy Dolnym Śląskiem na Warmii i Mazurach po roku 1945 pozostała relatywnie duża grupa Niemców, to próby ich integracji, także z powodu różnic religijnych, nie powiodły się. W efekcie zdecydowana większość zdecydowała się na emigrację.

Dr Irena Kurasz (Uniwersytet Wrocławski) omówiła sytuację mniejszości niemieckiej na Dolnym Śląsku. Także w tym regionie pozostało po 1945 roku wielu niemieckich mieszkańców, jednak ich przynależność narodowa nie była kwestionowana 
- ze wszystkimi korzyściami i problemami z tego faktu wynikającymi. Najważniejszym (i w pojedynczych przypadkach nierozwiązanym do dzisiaj) była kwestia obywatelstwa. Większość pozostałych po wojnie Niemców opuściła Dolny Śląsk w latach 1957-1962. Jak wynika chociażby z przeprowadzanych wywiadów, w części organizacji mniejszościowych dominują obecnie przybyli na ten teren w okresie powojennym Górnoślązacy.

Trzecia już konferencja Centrum Badań Mniejszości Niemieckiej zorganizowana została we współpracy z Instytutem Nauk Politycznych Uniwersytetu Warmińsko-Mazurskiego 6 kwietnia 2017 roku w Olsztynie. Czworo naukowców uczestniczących $\mathrm{w}$ realizacji projektu już w latach wcześniejszych analizowało z perspektywy różnych dyscyplin naukowych - antropologii, socjologii, historii i politologii - wywiady pogłębione przeprowadzone w roku 2016. Autorzy referatów reprezentowali różne ośrodki naukowe, co znakomicie wpłynęło na poszerzenie spojrzenia na podjęty temat. Moderatorem konferencji był prof. Arkadiusz Żukowski, dyrektor Instytutu Nauk Politycznych Uniwersytetu Warmińsko-Mazurskiego, zaś referaty wygłosili:

- prof. Krzysztof Gładkowski: „Obcy u siebie. Niemcy na Śląsku, Pomorzu, Warmii i Mazurach";

- dr Magdalena Lemańczyk: „Niemcy w Polsce po 1945 r. - od nieformalnych działań do formalnych organizacji";

- dr Adriana Dawid (Uniwersytet Opolski): „Wspomnienia - emocje - fakty. Wywiad jako źródło historyczne";

- dr Norbert Honka (Uniwersytet Opolski): „Postawa władz wobec Niemców w świetle materiałów wspomnieniowych świadków historii”.

\section{Opracowania naukowe}

Jednym z istotnych i wymiernych efektów realizacji zadania jest powstanie co roku kilku artykułów naukowych. Autorami są naukowcy zajmujący się różnymi aspektami funkcjonowania mniejszości niemieckiej w okresie powojennym i w dobie współczesnej. Podejmowane tematy dotyczą historii, tradycji, dziedzictwa Niemców w Polsce, ich szczegółowy zakres ustalany jest w ramach spotkań Rady Naukowej.

W roku 2016 opracowania autorstwa dr Magdaleny Lemańczyk i dr. Pawła Popielińskiego („Mniejszość niemiecka w województwie opolskim: początki i pierwsze lata funkcjonowania 15 DFK”), dr Adriany Dawid („Mniejszość niemiecka w województwie opolskim - analiza wywiadów realizowanych w ramach Centrum Badań Mniejszości Niemieckiej w 2016 roku”), Romana Szablickiego (,Deutsche Identitätangesichts der kulturellen Unterdrückung des Kommunismus - die alltäglichen Probleme der deutschen Minderheit im damaligen Polen”), dr Ireny Kurasz (,Refleksje nad historią Niemców na Dolnym Śląsku po II wojnie światowej w świetle wyników badań jakościowych”) oraz prof. Krzysztofa Gładkowskiego („Pamięć i tożsamość - Niemcy na Warmii i Mazurach") nawiązywały do wywiadów przeprowadzonych w dwóch pierwszych latach funkcjonowania Centrum? .

Centrum Badań Mniejszości Niemieckiej, Archiwum 2016, Rada Naukowa, http://www.haus. pl/cbmn-2016-rada-naukowa.html (dostęp: 13 marca 2018). 
Z kolei rok później podjęte zostały trzy bardzo różne zagadnienia ${ }^{10}$. Dr Ewa Gładkowska (Uniwersytet Warmińsko-Mazurski) w artykule „Niemieckie dziedzictwo na Warmii i Mazurach po roku 1945" przedstawiła specyficzną obecność Niemców, a w wielu miejscach już tylko śladów pozostałych po nich w polskiej części dawnych Prus Wschodnich. Dr Ewa Pogorzała (Państwowa Wyższa Szkoła Zawodowa w Zamościu) w opracowaniu „Polityka oświatowa państwa polskiego wobec mniejszości niemieckiej w latach 90. XX wieku" omówiła początkowy okres wprowadzania nauki języka niemieckiego jako języka mniejszości do systemu oświatowego. Natomiast dr Zbigniew Bereszyński w bardzo obszernym artykule „Komunistyczny aparat bezpieczeństwa i ludność niemiecka na Górnym Śląsku w latach 1945-1990" zaprezentował wyniki swoich badań prowadzonych w archiwach IPN. Autor szczególną uwagę poświęcił schyłkowemu okresowi PRL i podejmowanym wówczas próbom rejestracji stowarzyszeń Niemców w regionie. Opracowanie to w wersji rozszerzonej ukazało się drukiem i stanowi pierwszy tak szeroki opis procesu, który zaowocował uznaniem faktu istnienia mniejszości niemieckiej na Górnym Śląsku ${ }^{11}$. Jest też pierwszą publikacją w dorobku Centrum.

\section{Inne dzialania podejmowane w ramach projektu}

W roku 2016 przeprowadzone zostały badania ankietowe młodzieży gimnazjalnej z terenu województwa opolskiego korzystającej z możliwości nauki języka niemieckiego jako języka mniejszości narodowej. Punktem wyjścia była konstatacja, że wraz $\mathrm{z}$ wiekiem uczniów maleje ich zainteresowanie tą formą nauki. Powstaje zatem pytanie: czy nauczanie języka mniejszości wzmacnia tożsamość młodych ludzi, czy też jest przez nich raczej traktowane jako dodatkowe obciążenie?

Dr Irena Kurasz (Uniwersytet Wrocławski) zapytała uczniów dziesięciu gimnazjów o ich motywację, o używanie języka niemieckiego w codziennym życiu, o zwyczaje kultywowane w ich najbliższym otoczeniu. Pięć spośród wybranych szkół funkcjonuje w gminach z wysokim udziałem mniejszości niemieckiej - ponad 20\% (w świetle wyników Spisu Powszechnego z roku 2011), kolejnych pięć - tam, gdzie udział ten nie przekroczył 10\%.

Inną podjętą przez Centrum inicjatywą była próba zestawienia tzw. Bibliografii MN, czyli listy publikacji krajowych i zagranicznych podejmujących różne aspekty funkcjonowania i działalności mniejszości niemieckiej w Polsce. $Z$ kolei w powstałej w roku 2017 bazie danych zebrane zostały podstawowe informacje na temat historii poszczególnych kół lokalnych i stanu zachowania ich archiwów.

\section{Plany i perspektywy}

Pierwotne, ambitne założenia utworzenia „Instytutu Niemieckiego” musiały zostać zweryfikowane ze względu na dostępne możliwości finansowe, jak dotąd - kilkunasto-

10 Centrum Badań Mniejszości Niemieckiej, Artykuty naukowe http://www.haus.pl/cbmn-artykuly-naukowe.html (dostęp: 13 marca 2018).

1 Z. Bereszyński, Komunistyczny aparat bezpieczeństwa i ludność niemiecka na Górnym Ślasku w latach 1945-1990, Dom Współpracy Polsko-Niemieckiej, Gliwice - Opole 2017. 
krotnie mniejsze od środków, które do dyspozycji Centrum Dokumentacji Kultury i Historii Polaków w Niemczech przekazał rząd federalny.

W tej sytuacji jakiekolwiek porównania z instytucjami, takimi jak Instytut Serbołużycki (Sorbisches Institut) w Budziszynie, prowadzący badania nad historia, kulturą i językiem Serbołużyczan czy działające we Flensburgu tuż przy granicy niemiecko-duńskiej Europejskie Centrum Badań nad Mniejszościami (Europäisches Zentrum für Minderheitenfragen) są po prostu niemożliwe.

Wiele dobrych pomysłów - np. stworzenie kompleksowego programu badawczego czy powołanie własnego czasopisma naukowego - trzeba było odłożyć na przyszłość, a bieżące działania dopasować do realnych możliwości. W roku 2018 obok już wcześniej prowadzonych form działalności rozpoczęło się gromadzenie materiałów do słownika biograficznego mniejszości niemieckiej.

Rozwój Centrum pozostaje jednym z priorytetowych zadań mniejszości niemieckiej w najbliższej przyszłości, a jednocześnie stanowi szansę na wzbogacenie badań naukowych. Zakorzenienie instytucji i osób realizujących projekt w środowisku mniejszościowym, ciagle jeszcze dosyć hermetycznym, umożliwia docieranie do źródeł trudno dostępnych dla naukowców.

Czas pokaże, na ile nadzieje wiązane z Centrum zostaną spełnione. 